\title{
The Desert Hedgehog Signalling Pathway in Human Gonadal Development and Differences of Sex Development
}

\author{
Svenja Pachernegg ${ }^{a, b} \quad E^{2}$ Elizabeth Georges ${ }^{b}$ Katie Ayers ${ }^{a, b}$ \\ aReproductive Development Group, Murdoch Children's Research Institute, Melbourne, VIC, Australia; ${ }^{b}$ Department \\ of Paediatrics, University of Melbourne, Melbourne, VIC, Australia
}

\section{Keywords}

Desert hedgehog - Differences of sex development .

Gonadal dysgenesis . Testis development

\begin{abstract}
While the Hedgehog signalling pathway is implicated in numerous developmental processes and maladies, variants in the Desert Hedgehog $(D H H)$ ligand underlie a condition characterised by $46, X Y$ gonadal dysgenesis with or without peripheral neuropathy. We discuss here the role and regulation of $\mathrm{DHH}$ and its signalling pathway in the developing gonads and examine the current understanding of how disruption to this pathway causes this difference of sex development (DSD) in humans.

๑) 2021 S. Karger AG, Basel
\end{abstract}

\section{The Hedgehog Signalling Pathway in Humans}

The highly conserved Hedgehog $(\mathrm{HH})$ family of signalling molecules plays a central role in the development of numerous organs during embryogenesis. Disruption to the ligands or signalling pathway can cause a variety of genetic disorders at different stages [Sasai et al., 2019] as well as cancer [Doheny et al., 2020; Iriana et al., 2021].
The canonical $\mathrm{HH}$ signalling pathway has been the subject of numerous excellent reviews [Briscoe and Therond, 2013; Lee et al., 2016] and is only briefly described here with a focus on human. The HH morphogens are growth factors produced and secreted by a subset of cells. Humans, like many higher vertebrates, have $3 \mathrm{HH}$ genes; Sonic (SHH), Indian (IHH), and Desert (DHH) hedgehog. This review focuses on $\mathrm{DHH}$, the only ligand known to be involved in sex differentiation and differences of sex development (DSDs). All HH ligands undergo auto-processing and cleavage with the covalent addition of cholesterol [Porter et al., 1996] and palmitoylation [Pepinsky et al., 1998] by the hedgehog acyltransferase (HHAT) [Chamoun et al., 2001], which increase stability in the extracellular matrix and facilitate long-range spreading [Lewis et al., 2001; Zeng et al., 2001; Callejo et al., 2006]. Secreted HH ligands diffuse in a gradient, binding to the Patched (PTCH) receptor on target cells [Marigo et al., 1996; Motoyama et al., 1998]. PTCH is a constitutive repressor, indirectly destabilising the G-protein coupled receptor, Smoothened (SMO), the main pathway activator [Ayers and Therond, 2010]. Upon HH binding, PTCH is degraded in the endosome [Incardona et al., 2000] and repression of SMO is released, leading to downstream activation of the GLI family of transcription factors, GLI1, GLI2, and GLI3 [Bai et al., 2004]. karger@karger.com www.karger.com/sxd
(C) 2021 S. Karger AG, Basel

Karger ${ }^{\prime}=$
Correspondence to:

Katie Ayers, katie.ayers@mcri.edu.au 


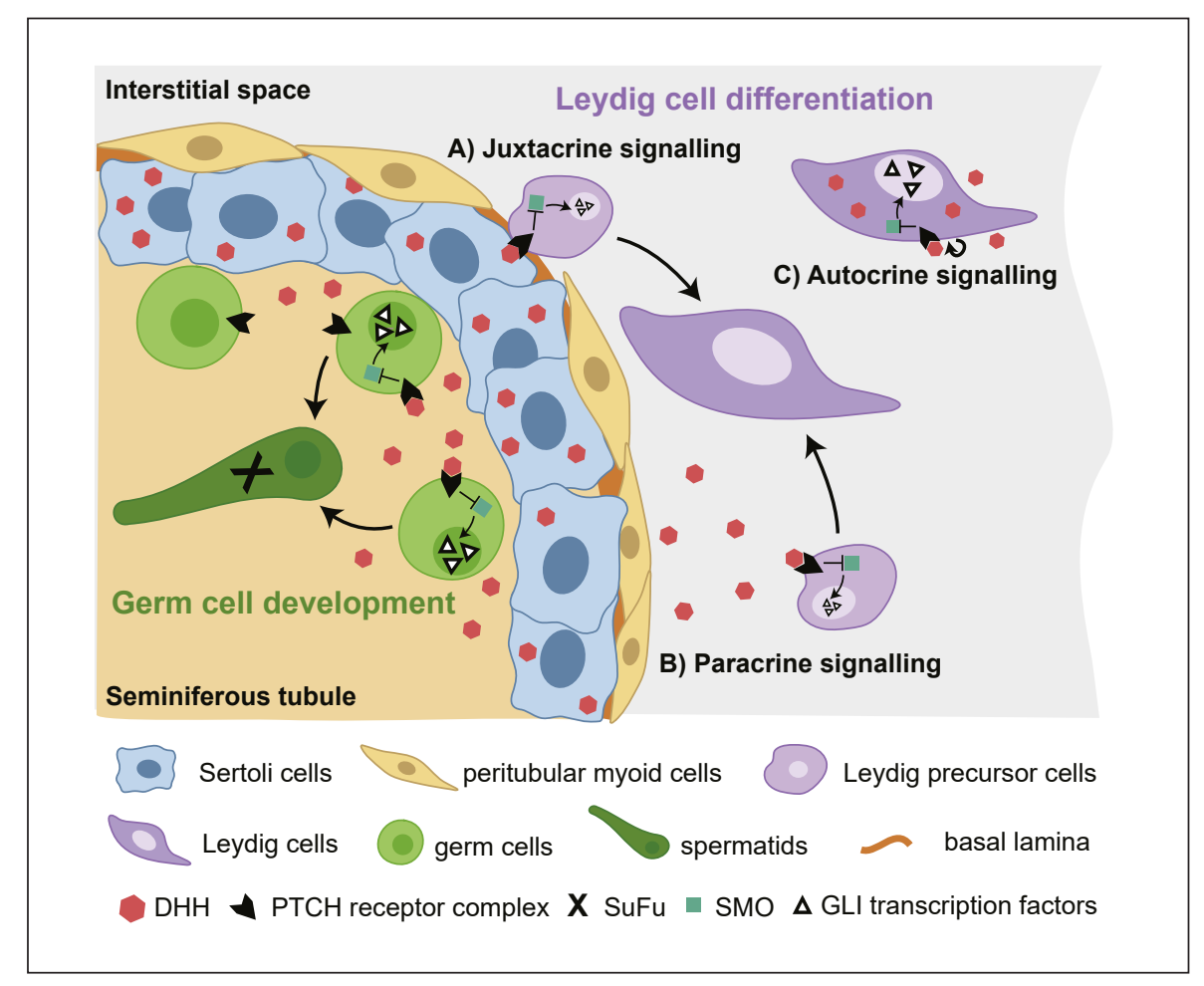

Fig. 1. DHH signalling during fetal testicular development. A During testicular development, the germ cells (green) are encased by the supporting Sertoli cells (blue) in the seminiferous tubules. Peritubular myoid cells (PMCs, ochre) lay down the basal lamina (orange) that surrounds the tubules. In the interstitial space between the tubules, the steroidogenic Leydig cells (purple) differentiate. B Sertoli cells produce DHH (red dots), and the immature interstitial cells express the PTCH receptor complex (black) and other DHH signalling components (not shown). DHH from the Sertoli cells is thought to act in a paracrine fashion to induce the differen-

\section{The Desert Hedgehog Pathway during Testis Development}

During embryogenesis the main roles of $\mathrm{DHH}$ are in the formation of the peripheral nerve sheath and the development of the testis [Briscoe and Therond, 2013]. Testis development from the bi-potential gonad is triggered by the expression of the Y chromosome linked SRY gene, which induces the differentiation of the Sertoli cells via SOX9. Following this, development of interstitial cell types such as the peritubular myoid (PTM) and fetal Leydig cells (FLCs) is initiated. The germ cells, which have migrated to the gonad early in its development, become encased in the seminiferous tubules along with the supportive Sertoli cells, surrounded by a basement membrane laid down by the PTM cells (Fig. 1a) [for a detailed review see Eggers et al., 2014].

DHH Signalling in Gonad Development tiation of precursors into the PMCs (which form the basal lamina) and the Leydig cells. Additionally, some studies have suggested autocrine DHH signalling within Leydig cells to maintain their steroidogenic function. C DHH also mediates germ cell maturation and spermatogenesis. DHH signalling likely starts in spermatogonia and primary spermatocytes, which express the PTCH receptor complex as well as pathway activators. Elongating spermatids express SuFu (black cross), a DHH pathway inhibitor, which might indicate that $\mathrm{DHH}$ signalling is switched off at the spermatid stage.

Most of what we know about the role of the DHH signalling pathway during testis development stems from animal models. This is summarised here. In mice, Dhh expression does not overlap with either Shh or $I h h$, and $D h h$ is the main $H h$ involved in gonad development [Bitgood and McMahon, 1995; Shima et al., 2004]. Dhh expression in the mouse gonad starts from $11.5 \mathrm{dpc}$ (days post coitum) and is maintained into adulthood [Bitgood et al., 1996; Yao et al., 2002; Szczepny et al., 2006]. In the early stages, Dhh expression is restricted to the Sertoli cells, likely inducing PTM and LC differentiation in a paracrine fashion [Bitgood et al., 1996; Clark et al., 2000; Pierucci-Alves et al., 2001; Yao et al., 2002] (Fig. 1b). PTM and LC precursors express the Dhh pathway receptors Ptch1 and Ptch2 from 11.5 dpc [Bitgood et al., 1996; Carpenter et al., 1998; Clark et al., 2000; Yao et al., 2002], and the Gli transcription factors (Gli1-3) are observed in the 
fetal and adult interstitium from $14.5 \mathrm{dpc}$ [Szczepny et al., 2006; Barsoum and Yao, 2011]. The role of Dhh appears to be conserved in the marsupial animal model, the tamar wallaby, where $\mathrm{DHH}$ is the only $\mathrm{HH}$ expressed during gonadal development [Chung et al., 2012], found in preSertoli cells at the beginning of cord formation, when its receptors $P T C H 1$ and $P T C H 2$ are also expressed [O'Hara et al., 2011].

In mice, Dhh signalling initiates FLC differentiation and maturation through upregulation of the transcription factor $S f 1$ (steroidogenic factor 1). Sf1 in turn upregulates the expression of the steroidogenic enzymes $C y$ p11a1 (cholesterol side-chain cleavage; P450ssc) and $\mathrm{Hs}$ d3b1 (hydroxyl-delta-5-steroiddehydrogenase, 3 beta-and steroid delta-isomerase 1) [Yao et al., 2002; Park et al., 2007; Brokken et al., 2009]. Constitutively active Dhh signalling in Sf1-positive LC progenitor cells led to an increased number of FLCs in mouse fetal testis [Barsoum et al., 2013], while the treatment of fetal gonad explant cultures with an $\mathrm{Hh}$ signalling inhibitor severely disrupted FLC differentiation [Yao and Capel, 2002]. Dhh has also been implicated in adult LC (ALC) differentiation, increasing their proliferation and transition rate through their stages of development [reviewed in Ye et al., 2017]. Dhh may also maintain ALC steroidogenic function (Fig. 1b), as the loss of testosterone production in conditional Wt1 (Wilms tumor protein) null mice could be partially rescued by treatment with SAG (a SMO agonist) [Chen et al., 2014]. Interestingly, Dhh protein expression has been described in mouse ALCs together with Ptch1 and Smo, leading to the speculation that ALCs are capable of autocrine signalling [Morales et al., 2009], although further evidence is needed (Fig. 1b).

Dhh ablation in animal models confirms its importance during gonadal development. Dhh null XY mice display a range of testicular defects, depending on their genetic background. In some cases, XY nulls have abnormal FLC and ALC development with an interstitium containing primarily undifferentiated cells, leading to testosterone insufficiency [Clark et al., 2000; Yao et al., 2002]. Testis with disorganised and irregularly shaped Sertoli cells, abnormal peritubular tissue, and discontinued basal lamina that result in irregular and anastomotic tubules with germ cells located outside of the cords have also been described in mice lacking Dhh [Clark et al., 2000; Pierucci-Alves et al., 2001]. In some cases, Dhh null testes are significantly smaller, with seminiferous tubules only thinly lined with Sertoli cells [Bitgood et al., 1996]. Dhh mutant rats also show impaired LC development and insufficient androgen production [Kawai et al., 2011]. Wal- laby ex vivo testicular cultures with inhibited Hh signalling have disorganised cords with some germ cells outside, likely due to a perturbation in the PTM cells and basal lamina, suggesting conservation of the mechanism [Chung et al., 2012].

Dhh also regulates germ cell maturation/spermatogenesis [reviewed in Walterhouse et al., 2003] (Fig. 1c). Adult XY Dhh null mice are infertile due to a lack of mature sperm, as germ cells do not progress towards the final stages of spermatogenesis [Bitgood et al., 1996]. Dhh signalling likely begins in spermatogonia and primary spermatocytes, which express the Ptch receptors, the Dhh activators Smo and $\mathrm{Fu}$, and the Gli transcription factors [Persengiev et al., 1997; Carpenter et al., 1998; Fan et al., 2007; Morales et al., 2009]. At later germ cell maturation stages, Dhh signalling seems to be switched off in round and elongating spermatids, as indicated by both a shift of Gli1 protein expression from the nucleus to the cytoplasm [Kroft et al., 2001] and the expression of SuFu (Suppressor of Fused), a negative regulator of the Hh signalling pathway, in these cells [Szczepny et al., 2006].

\section{Desert Hedgehog in Human Testicular Development}

In humans, $D H H$, composed of 3 exons, is located at $12 \mathrm{q} 12.13$ and encodes a protein of 396 amino acids [Tate et al., 2000]. Like the other $\mathrm{HH}$ proteins, $\mathrm{DHH}$ is likely produced as a $45 \mathrm{kDa}$ precursor with the $25 \mathrm{kDa} \mathrm{C}$-terminal driving autolytic cleavage assisted by the covalent addition of a cholesterol moiety to the $19 \mathrm{kDa}$ N-terminal fragment, thought to be the active molecule [Mann and Beachy, 2004]. However, the extent of DHH processing in the human embryonic gonads is unknown. DHH can be cleaved in an in vitro system [Tajouri et al., 2018], yet DHH expressed in cultured cells such as HEK293T cells is often uncleaved [Pettigrew et al., 2014; Ayers et al., 2019]. Indeed, domain swapping experiments have demonstrated that the DHH C-terminal is less efficient in cleaving the SHH N-terminal than the SHH C-terminal [Pettigrew et al., 2014]. In culture, uncleaved DHH is not effectively secreted and accumulates intracellularly, unable to elicit paracrine pathway activation [Pettigrew et al., 2014], yet these cells are still able to induce HH signalling in a juxtacrine assay, including the activation of LCs derived from immature mouse testes (TM3 cells) [Pettigrew et al., 2014]. Based on this, it has been proposed that $\mathrm{DHH}$ is not processed or secreted in the Sertoli cells, instead eliciting a cellular response in the LCs in a juxtacrine fashion. Although based on the position and pro- 


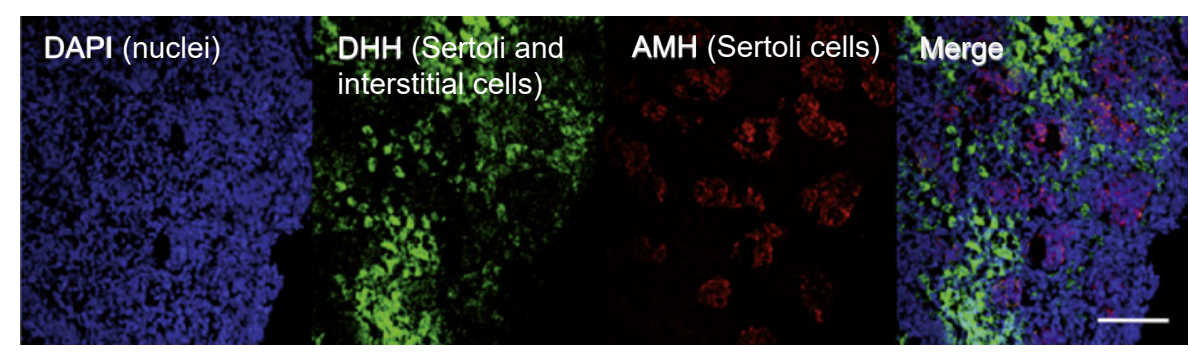

Fig. 2. DHH expression in human fetal testis. Buonocore et al. [2019] analysed DHH protein expression in human fetal testis. At 9 weeks post conception, they found cytoplasmic DHH primarily in interstitial Leydig cells, with some staining in Sertoli cells (AMH-positive). The source of DHH in Leydig cells is not known

posed effects of human $\mathrm{DHH}$ genetic variants, others have proposed that $\mathrm{DHH}$ auto-processing is necessary in the human gonads [Elzaiat et al., 2020].

Recombinant human DHH shows an affinity to its PTCH receptor complex comparable to $\mathrm{SHH}$ and $\mathrm{IHH}$ [Pathi et al., 2001] and is therefore thought to activate the same pathway during development, and DHH likely plays a conserved role in the testis although some interesting differences may exist in humans. Single cell RNA seq data from human fetal gonads [Li et al., 2017] (https://rgv.genouest.org/) [Darde et al., 2015, 2019] show DHH expression in the Sertoli cells with a peak in expression at 12 gestational weeks. Pathway receptor/targets $P T C H 1$ and $\mathrm{PTCH} 2$ become strongly expressed at 10 weeks of gestation in Leydig precursors, mature LCs, and primordial germ cells (PGCs). Similarly, the GLI genes can be observed in the same cell clusters with the strongest expression between 20 and 25 weeks of gestation. Of note, the $P T C H$ receptor complex shows weak expression in Sertoli cells [Li et al., 2017], and the pathway activator SMO is expressed throughout the human gonad but absent from the Sertoli cells. This might suggest DHH produced by Sertoli cells can bind these cells via PTCH yet cannot activate signalling due to the absence of SMO. Just one study has looked at DHH protein in human fetal testis using immunohistochemistry and describes cytoplasmic expression of DHH predominantly in interstitial LCs but also in Sertoli cells at 9 weeks post conception [Buonocore et al., 2019] (Fig. 2). It is not clear whether this Leydig $\mathrm{DHH}$ originated in the secreting Sertoli cells or whether LCs are also a source of $\mathrm{DHH}$, and $\mathrm{DHH}$ staining is still needed in earlier development phases (i.e., 5-7 weeks gestation) to truly understand its role in human testis differentiation. At later time points (19 gestational weeks), $\mathrm{DHH}$ protein expression is reportedly predominantly lo- and may have originated in Sertoli cells or in Leydig cells themselves. The latter would suggest a degree of autocrine DHH signalling in human Leydig cells. Figure reused with permission by authors from Buonocore et al. [2019]. calised to Sertoli cells [Fowler et al., 2008], and maternal smoking during pregnancy appears to lead to a decrease in both $\mathrm{DHH}$ and PTCH1 expression in male fetuses. Since maternal smoking is also associated with reduced testis size with decreased sperm count and quality in male offspring, a phenotype intriguingly similar to that of the Dhh knockout mice, it has been speculated that diminished $\mathrm{DHH}$ expression is responsible for this phenotype [Fowler et al., 2008].

\section{Genetic Variants in DHH Cause 46,XY Gonadal Dysgenesis}

It is well established that pathogenic variants in $\mathrm{DHH}$ are a rare cause of $46, \mathrm{XY}$ DSD in humans, in particular causing 46,XY partial or complete gonadal dysgenesis with or without peripheral neuropathies (OMIM 607080, OMIM 233420). The $\mathrm{DHH}$ gene is highly conserved and shows 20 different $\mathrm{DHH}$ pathogenic variants that have been published in 24 cases (Fig. 3, Table 1) with variants falling in both the $\mathrm{N}$ - and C-terminal domains (Fig. 3) [Umehara et al., 1999, 2000; Sugie et al., 2002; Canto et al., 2004, 2005; Das et al., 2011; Werner et al., 2015; Eggers et al., 2016; Paris et al., 2017; Sato et al., 2017; Baldinotti et al., 2018; Rothacker et al., 2018; Tajouri et al., 2018; Ayers et al., 2019; Buonocore et al., 2019; Neocleous et al., 2019]. Given that DHH is a potent growth factor that signals in a concentration-dependent manner, it is not surprising that the vast majority of pathogenic cases reported are biallelic (homozygous or compound heterozygous), and the contribution of heterozygous variants in $\mathrm{DHH}$ to DSD is unclear. Two patients reported to carry a heterozygous variant (p.Leu363Cysfs*4) in $\mathrm{DHH}$ also had sex chromosome mosaicism $(45, \mathrm{X} / 46, \mathrm{XY})$ [Canto et al., 2005] (Ta- 


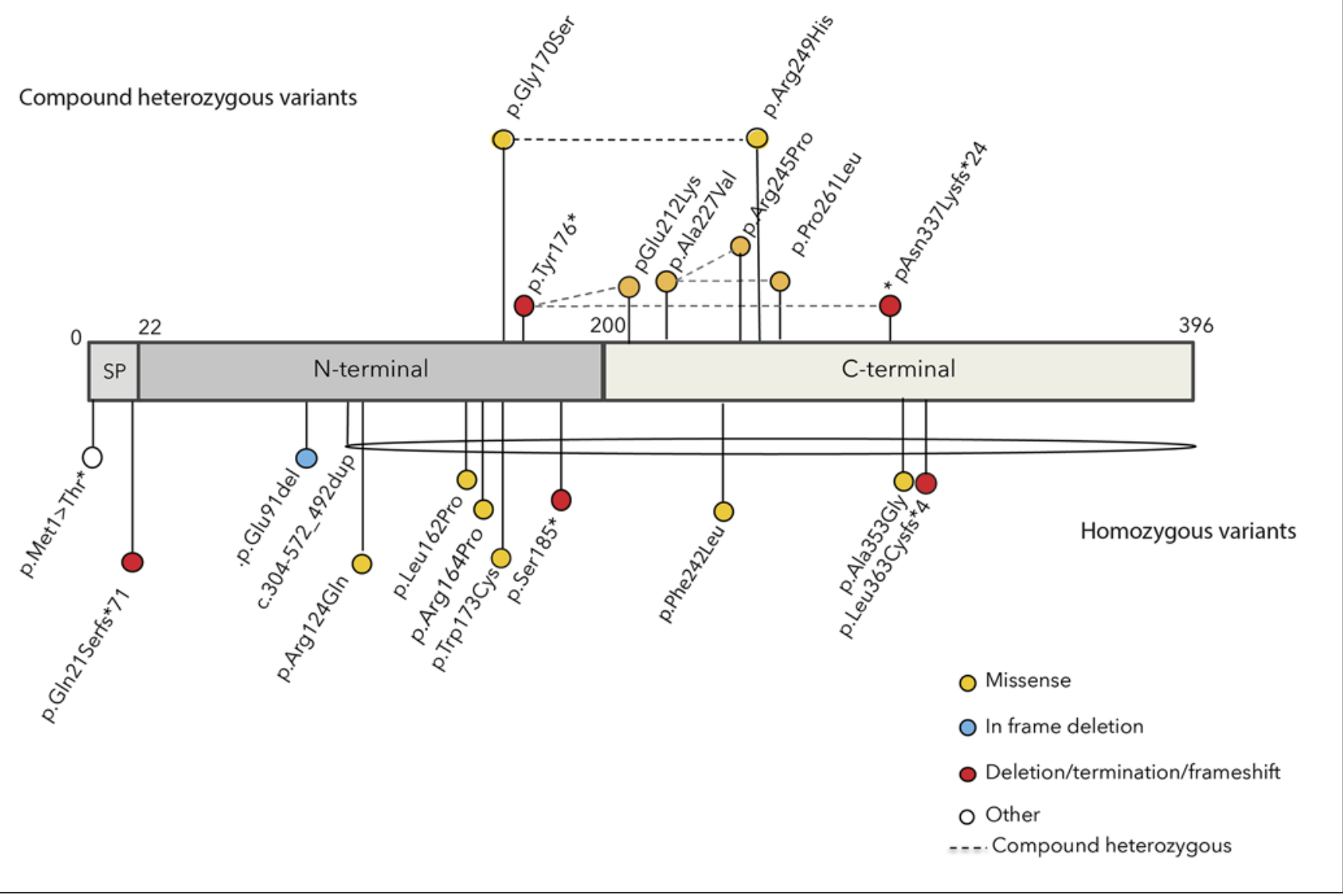

Fig. 3. Genetic variants in $D H H$ reported in patients with DSD. A schematic figure showing the protein position of previously reported variants in $\mathrm{DHH}$. Compound heterozygous variants are depicted by a dotted line joining the 2 variants and are shown above

ble 1), and our group has described a number of DSD patients with heterozygous $\mathrm{DHH}$ variants although our functional studies have suggested that these are unlikely to be the major cause [Ayers et al., 2019]. Most patients with bi-allelic $D H H$ variants are 46,XY female, with just 2 reportedly raised as males (Table 1). Complete gonadal dysgenesis has been described in 13 patients with streak gonads and/or Müllerian structures indicating no functional gonadal tissue (Table 1). Ten cases of confirmed or suspected partial gonadal dysgenesis have also been reported. One patient had histological findings suggestive of Leydig cell hypoplasia (Table 1). Five patients with $\mathrm{DHH}$ variants have reported gonadal cancer, and 7 had DHHassociated neuropathies (Table 1).

Several groups have used functional genomics to understand the underlying pathology of variants (Table 2). the protein, homozygous variants are below. Yellow circles show missense variants, blue are in-frame deletions, and red are variants that cause frameshifts or premature stop codons. SP, signal peptide.

Overexpression constructs of tagged $\mathrm{DHH}$ proteins have been used to assay cellular localisation and protein cleavage with varying results which appear to depend on the cells used. Our group found that DHH expressed in HEK293T cells was mostly full length, and expression levels/cleavage did not significantly differ for any variant tested with the exception of the frameshift variant p.Leu363CysFs*4 where no full length protein was observed (Table 2) [Ayers et al., 2019]. In these cells, transfected DHH was expressed in the cytoplasm and cell membrane. Cellular localisation of the $11 \mathrm{DHH}$ variants tested did not differ to the wild type, although the p.Arg164Pro variant had a slightly reduced staining [Ayers et al., 2019]. In contrast, another study found that $\mathrm{DHH}$ is cleaved when expressed in HeLa cells, and that a number of patient variants had reduced or absent self-cleavage 


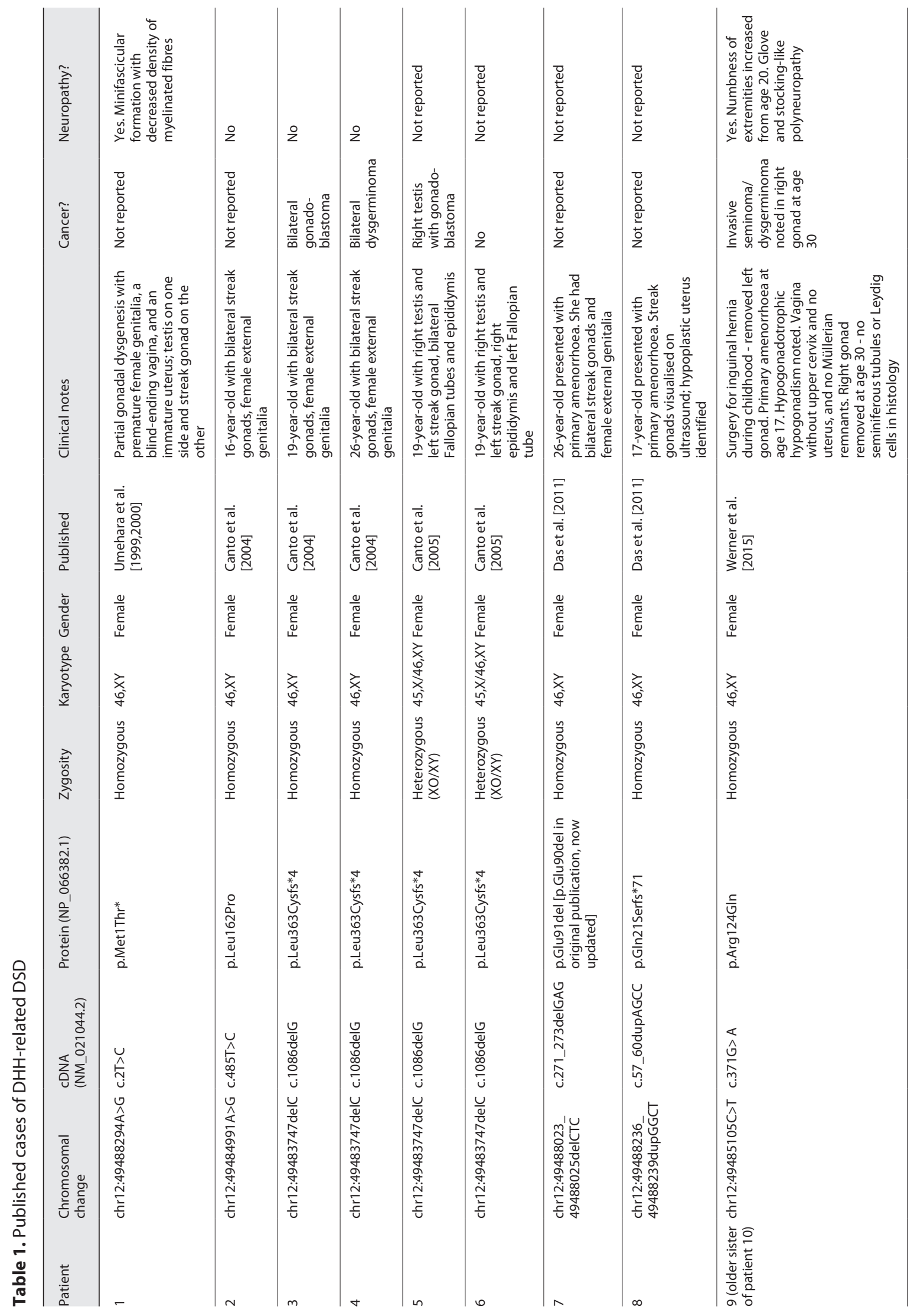




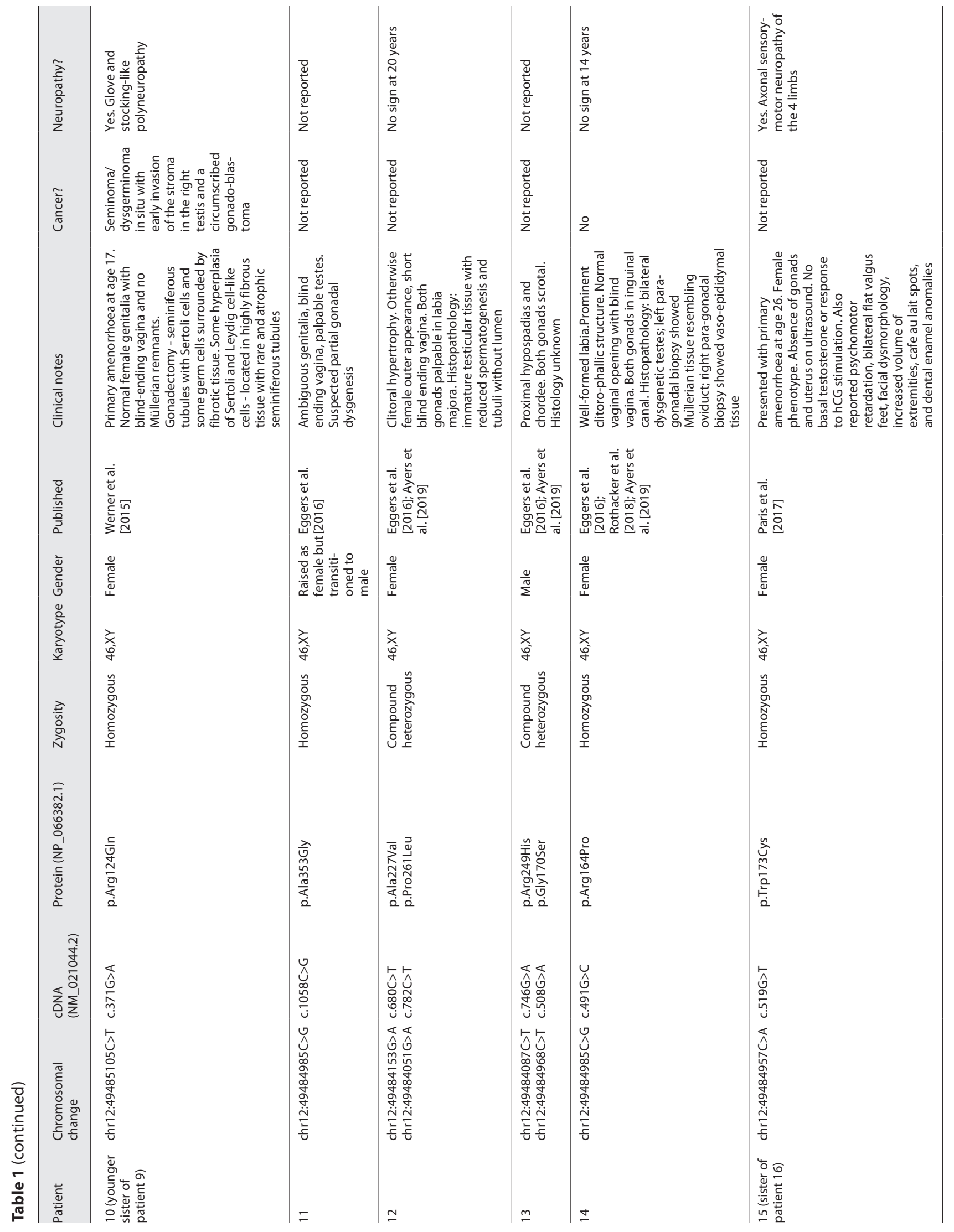



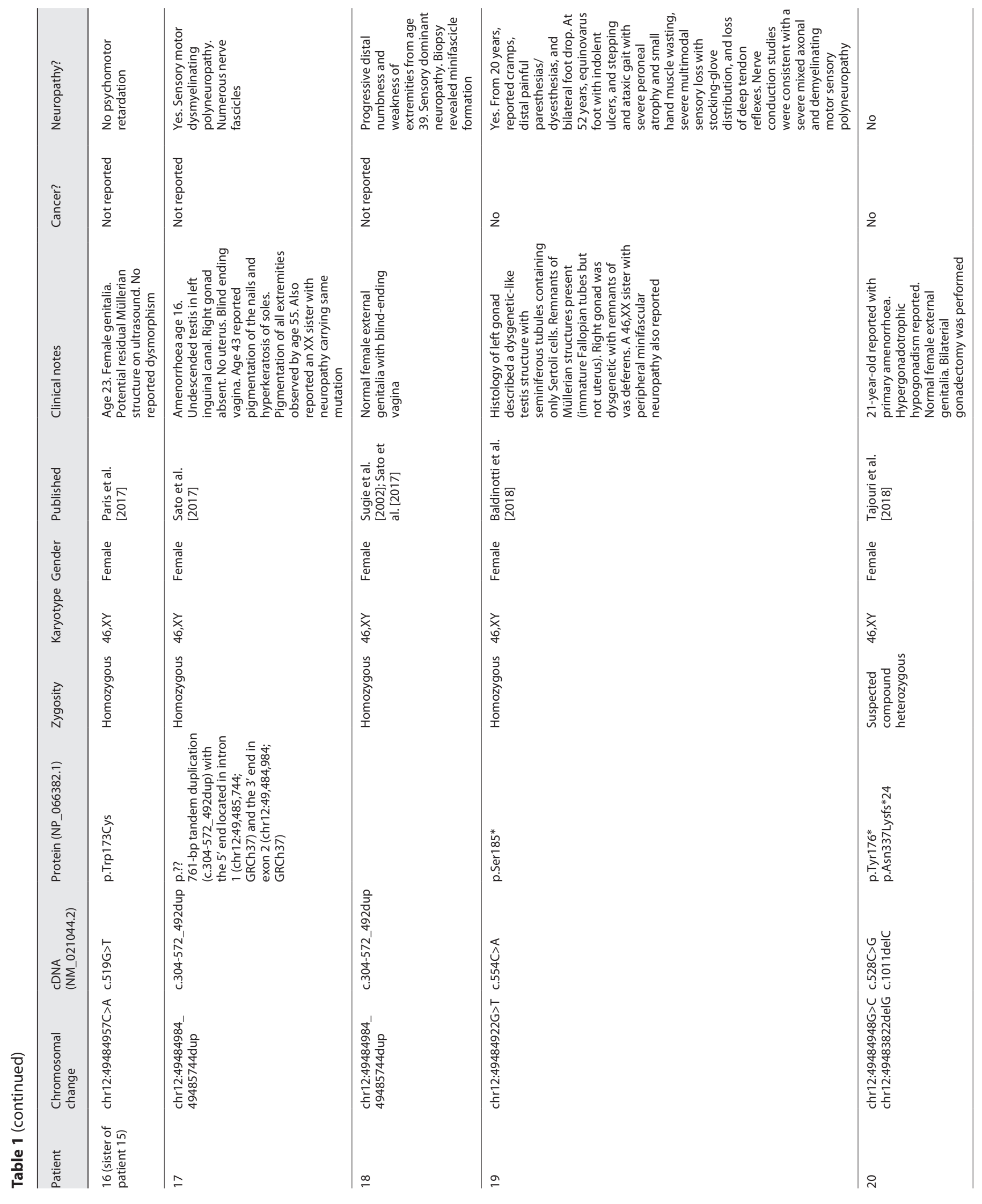


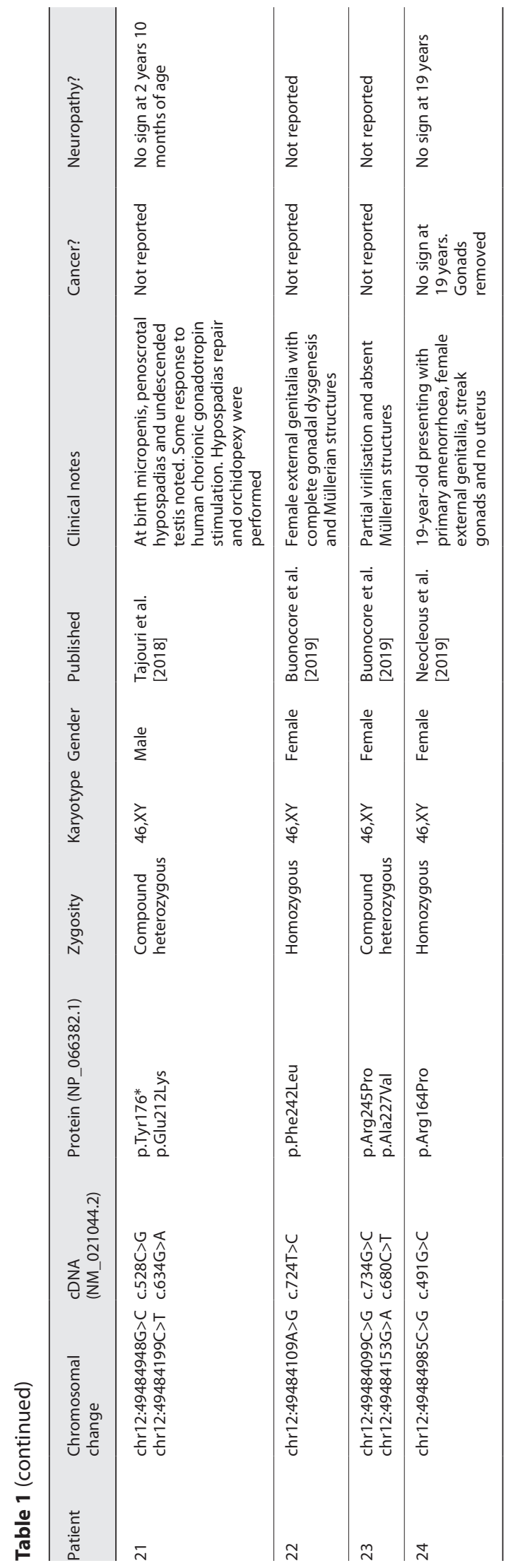

[Elzaiat et al., 2020] (Table 2). In addition, HeLa cells transfected with DHH-GFP variants had 2 patterns of intracellular localisation, termed by the authors "granular" (cytoplasmic expression) and "ring-type" (homogenous expression surrounding the nucleus). A significantly lower proportion of the granular-type staining was described in some of the variants with impaired protein processing [Elzaiat et al., 2020] (Table 2). A cell-free in vitro cleavage assay has also shown that a fusion human $\mathrm{DHH}$ protein can undergo cleavage (with the addition of DTT or $\beta$-mercaptoethanol) [Tajouri et al., 2018] and $2 \mathrm{C}$-terminus patient variants led to reduced [p.(Glu212Lys)] or absent [p.(Asn337Lysfs*24)] cleavage efficiency in this system [Tajouri et al., 2018]. Interestingly, using HEK293T cells expressing wild type or variant $\mathrm{DHH}$ co-cultured with TM3 mouse LCs (known to be responsive to DHH [Pathi et al., 2001]), our group found reduced or absent pathway activity for $9 \mathrm{DHH}$ variants (Table 2). This suggests that despite the lack of cleavage, variants in $\mathrm{DHH}$ affect its activity on LCs in this system.

\section{Additional DHH Pathway Genes Contributing to Human Reproductive Disorders}

\section{Hedgehog Acetyltransferase}

HHAT is a palmitoyl acyltransferase for $\mathrm{HH}$ proteins [Buglino and Resh, 2008], and its loss in mice affects Hh secretion and long-range diffusion, resulting in holoprosencephaly, acrania, and agnathia, likely due to reduced Shh signalling [Dennis et al., 2012], as well as disrupted testis cord formation and reduced LC differentiation [Callier et al., 2014]. In humans, HHAT is expressed in embryonic ovaries and testes at 9 weeks gestation, where it is higher in Sertoli cells compared to LCs [Callier et al., 2014]. Recessive variants in HHAT cause Nivelon-Nivelon-Mabille syndrome (NNMS; OMIM 600092), characterised by progressive microcephaly, vermis hypoplasia, and skeletal dysplasia. Just one 46,XY patient with NNMS has been described [Nivelon et al., 1992; Thauvin-Robinet et al., 2005; Callier et al., 2014], and this individual was born with normal external female genitalia. Histology confirmed testicular dysgenesis with dysplastic/immature seminiferous tubules and a dense interstitial compartment with reduced numbers of LCs. Persistent Müllerian and Wolffian duct structures were noted. The patient carried a homozygous HHAT p.Gly287Val missense variant inherited from unaffected carrier parents, which fell in the $\mathrm{O}$-acyltransferase domain and abolished palmitoylation of $\mathrm{HH}$ proteins [Callier et al., 2014]. This sug- 
Table 2. Functional genomic findings for the $18 \mathrm{DHH}$ variants reported

\begin{tabular}{|c|c|c|c|}
\hline Variant & DHH protein, cleavage, and processing & Subcellular localisation & Activity \\
\hline p.Met1Thr* & $\begin{array}{l}\text { Missense mutation at the initiating codon which } \\
\text { resulted in failure of translation of the } \mathrm{DHH} \text { gene }\end{array}$ & & \\
\hline $\begin{array}{l}\text { p.Glu91del [p.Glu90del in } \\
\text { original publication] }\end{array}$ & $\begin{array}{l}\text { Reduced cleavage in HeLa cells [Elzaiat et al., } \\
\text { 2020] }\end{array}$ & & $\begin{array}{l}\text { Loss of activity in HEK/TM3 co- } \\
\text { culture assay [Ayers et al., 2019] }\end{array}$ \\
\hline p.Arg124GIn & $\begin{array}{l}\text { Slightly reduced cleavage in HeLa cells [Elzaiat et } \\
\text { al., 2020] }\end{array}$ & & $\begin{array}{l}\text { Partial loss of activity in HEK/TM3 } \\
\text { co-culture assay [Ayers et al., 2019] }\end{array}$ \\
\hline p.Leu162Pro & $\begin{array}{l}\text { Abolished cleavage in HeLa cells [Elzaiat et al., } \\
\text { 2020] }\end{array}$ & $\begin{array}{l}\text { Altered subcellular localisation in } \\
\text { HeLa cells [Elzaiat et al., 2020] }\end{array}$ & $\begin{array}{l}\text { Loss of activity in HEK/TM3 co- } \\
\text { culture assay [Ayers et al., 2019] }\end{array}$ \\
\hline p.Arg164Pro & $\begin{array}{l}\text { Abolished cleavage in HeLa cells [Elzaiat et al., } \\
\text { 2020] }\end{array}$ & $\begin{array}{l}\text { Slight reduction in expression levels } \\
\text { [Ayers et al., 2019] }\end{array}$ & $\begin{array}{l}\text { Loss of activity in HEK/TM3 co- } \\
\text { culture assay [Ayers et al., 2019] }\end{array}$ \\
\hline p.Gly170Ser & $\begin{array}{l}\text { Reduced cleavage in HeLa cells [Elzaiat et al., } \\
\text { 2020] }\end{array}$ & & $\begin{array}{l}\text { Partial loss of activity in HEK/TM3 } \\
\text { co-culture assay [Ayers et al., 2019] }\end{array}$ \\
\hline p.Trp173Cys & $\begin{array}{l}\text { Abolished cleavage in HeLa cells [Elzaiat et al., } \\
\text { 2020] }\end{array}$ & $\begin{array}{l}\text { Altered subcellular localisation in } \\
\text { HeLa cells [Elzaiat et al., 2020] }\end{array}$ & \\
\hline p.Glu212Lys & $\begin{array}{l}\text { Reduced cleavage efficiency in in vitro time } \\
\text { course [Tajouri et al., 2018] }\end{array}$ & & \\
\hline p.Ala227Val & $\begin{array}{l}\text { Abolished cleavage in HeLa cells [Elzaiat et al., } \\
\text { 2020] }\end{array}$ & $\begin{array}{l}\text { Altered subcellular localisation in } \\
\text { HeLa cells [Elzaiat et al., 2020] }\end{array}$ & $\begin{array}{l}\text { Loss of activity in HEK/TM3 co- } \\
\text { culture assay [Ayers et al., 2019] }\end{array}$ \\
\hline p.Arg249His & $\begin{array}{l}\text { Reduced cleavage in HeLa cells [Elzaiat et al., } \\
\text { 2020] }\end{array}$ & & $\begin{array}{l}\text { Partial loss of activity in HEK/TM3 } \\
\text { co-culture assay [Ayers et al., 2019] }\end{array}$ \\
\hline p.Pro261Leu & $\begin{array}{l}\text { Abolished cleavage in HeLa cells [Elzaiat et al., } \\
\text { 2020] }\end{array}$ & $\begin{array}{l}\text { Altered subcellular localisation in } \\
\text { HeLa cells [Elzaiat et al., 2020] }\end{array}$ & $\begin{array}{l}\text { Loss of activity in HEK/TM3 co- } \\
\text { culture assay [Ayers et al., 2019] }\end{array}$ \\
\hline p.Asn337Lysfs*24 & $\begin{array}{l}\text { Abolished cleavage in in vitro assay [Tajouri et al., } \\
\text { 2018] }\end{array}$ & & \\
\hline p.Arg353Gly & $\begin{array}{l}\text { Abolished cleavage in HeLa cells [Elzaiat et al., } \\
\text { 2020] }\end{array}$ & & \\
\hline p.Leu363Cysfs*4 & $\begin{array}{l}\text { Truncated protein detected in Western blot with } \\
\text { less expression [Ayers et al., 2019] }\end{array}$ & $\begin{array}{l}\text { Truncated form still expressed in } \\
\text { HEK cells [Ayers et al., 2019] }\end{array}$ & $\begin{array}{l}\text { Loss of activity in HEK/TM3 co- } \\
\text { culture assay [Ayers et al., 2019] }\end{array}$ \\
\hline
\end{tabular}

gests that loss of HHAT disrupts DHH signalling in the human testis.

\section{Cilia, Ciliopathies, and DSD}

An interesting feature to vertebrate $\mathrm{HH}$ signalling is the importance of the primary cilia [Huangfu et al., 2003; Bangs and Anderson, 2017]. In the absence of HH, PTCH is present in the cilia and when $\mathrm{HH}$ binding inactivates PTCH, SMO accumulates in the cilia [Corbit et al., 2005; Rohatgi et al., 2007] where it controls the activation of the GLIs which are enriched at the cilia tip. Dhh signalling is thought to be regulated via the primary cilium in mouse LCs, as shown in TM3 culture cells [Nygaard et al., 2015], and cilia are also likely to play a role in human testis $\mathrm{DHH}$ signalling. PMCs are positive for primary cilia, and while mature LCs do not commonly possess primary cilia, less differentiated LCs often do [Nygaard et al., 2015]. This would indicate that $\mathrm{DHH}$ signalling proceeds via the primary cilia in these cells. This idea is supported by findings in humans where defects in ciliary assembly or trafficking lead to numerous developmental disorders collectively referred to as ciliopathies. These include Bardet-Biedl (BBS), Joubert, and Meckel-Gruber syndromes [Reiter and Leroux, 2017]. Reproductive disorders are not uncommon in ciliopathies. For example, BBS patients often present with phenotypes such as LC or general testis hypoplasia [Green et al., 1989]. It has not yet been established whether these phenotypes are due to primary failure in testis differentiation or later from a disrupted adrenal-pituitary-gonadal axis [Soliman et al., 1996], and therefore, further work is required to understand the exact role of primary cilia in $\mathrm{DHH}$ signalling in the testis. 
In addition, enzymes involved in lipid biosynthesis in the ciliary microenvironment that promote Hedgehog signalling may also be important contributors to DSD. DHCR7 (7-dehydrocholesterol reductase) is an enzyme that synthesises cholesterol, and recent studies have shown that DHCR7 localises near the ciliary base to prime the cilia for $\mathrm{HH}$ pathway activation [Findakly et al., 2021]. Children with variants in DHCR7 develop Smith-LemliOpitz syndrome (SLOS; OMIM 270400), with elevated 7-DHC and low cholesterol levels and a broad phenotypic spectrum including underdeveloped external genitalia and poorly differentiated testicular tissue. These studies were not carried out in gonadal tissue/cell lines; however, given that $\mathrm{HH}$ molecules like $\mathrm{DHH}$ are cholesterol-modified and that cilia-based activation may require local cholesterol synthesis, it would be interesting to investigate whether variants in DHCR7 lead to DSD via a decrease in gonadal DHH signalling.

\section{Outstanding Questions}

Despite the overwhelming evidence that $\mathrm{DHH}$ variants cause 46,XY gonadal dysgenesis, the exact role of $\mathrm{DHH}$ and its signalling pathway in the human gonad are still not well understood. Outstanding questions surround the expression, cleavage, and secretion of the $\mathrm{DHH}$ ligand in the human gonads. Further research into the relative importance of juxtacrine, paracrine, and even autocrine signalling is required and may reveal differential mechanisms for each gonadal cell type. Thus far, this research has been severely impeded by the difficulty in obtaining primary human embryonic gonadal tissue at a relevant time point for fetal gonadal development (i.e., weeks 5-9 of gestation). To add to this, an adequate human embryonic gonadal cell line is currently lacking. We and others have begun to address this issue using differentiation methods for pluripotent stem cells into several cell types of the embryonic gonad, that is, bipotential cells, early Sertoli cells, and immature LCs [Bucay et al., 2009; Buganim et al., 2012; Yang et al., 2015, 2017; Sepponen et al., 2017; Rodriguez Gutierrez et al., 2018; Chen et al., 2019; Knarston et al., 2020]. We have observed the induction of $D H H$ expression in $3 \mathrm{D}$ organoid cultures, thus providing a valuable future tool to investigate the role of key testicular genes such as $D H H$ during human fetal testis development [Knarston et al., 2020].

Interestingly, animal models suggest that the major role of Sertoli-secreted Dhh is to drive differentiation of the in- terstitial LC and PTM cells, and mice nulls often have testes with reduced populations of these cells and disrupted testis cords. However, in humans, the majority of patients with bi-allelic DHH variants demonstrate complete gonadal dysgenesis, a more severe phenotype. This suggests that DHH may play an additional role in human testis, for instance in Sertoli cell differentiation or maintenance. Alternatively, human gonads may show a greater sensitivity to disruption of the testis cord basement membrane, observed in several animal models, perhaps resulting in complete degeneration/loss of the gonad. Interestingly, $\mathrm{DHH}$ has been suggested to play a role in vascular endothelial cells, in particular in maintaining the integrity of the bloodbrain and the blood-nerve barrier by regulating endothelial tight junction expression [Chapouly et al., 2016; Caradu et al., 2018; Hollier et al., 2020]. DHH has also been shown to regulate the expression of proangiogenic factors in Schwann cells [Renault et al., 2013]. A similar role for $\mathrm{DHH}$ in the formation of the blood-testis barrier or testis vasculature is therefore feasible.

A DHH genetic diagnosis can guide clinical management and patient monitoring, in particular, in relation to gonadal malignancies and neuropathies. Indeed, 7 of the 24 patients previously reported with $\mathrm{DHH}$-associated DSD also had neuropathy, and 5 patients had reported gonadal cancers (including seminoma in situ, dysgerminoma, and gonadoblastoma) [Canto et al., 2004, 2005; Werner et al., 2015]. However, functional studies are yet to reveal which $\mathrm{DHH}$ variants carry greater risk of these additional features or whether this is due to additional environmental or genetic factors. These genotype-phenotype correlations require more investigation and may be revealed only with additional reported cases and a greater understanding of the $\mathrm{DHH}$ pathway role and regulation in the human embryo.

It is also interesting that very few additional $\mathrm{DHH}$ pathway genes have been implicated in DSD thus far. This is likely explained by the fact that $\mathrm{DHH}, \mathrm{SHH}$, and IHH all converge on a central pathway, mutations in which lead to severe phenotypes or even embryonic lethality. In these cases, a fertility or sex-reversal phenotype may be overlooked. Currently, less than $50 \%$ of patients born with a DSD will receive a genetic indication [Eggers et al., 2016]. Future advances in sequencing technologies may identify variants in additional DHH signalling pathway components with gonadal-specific mosaicism as genetic risk factors or as oligogenetic contributors to DSD. 


\section{Conclusion}

The $\mathrm{HH}$ signalling pathway is a well-studied regulator of embryonic development and when disrupted causes severe genetic defects. The $\mathrm{HH}$ morphogen $\mathrm{DHH}$ specifically regulates fetal gonadal development, and $\mathrm{DHH}$ variants cause 46,XY gonadal dysgenesis in humans, sometimes combined with peripheral neuropathy. A detailed understanding of how DHH signalling works in human is still lacking, and more research is required to understand the pathological mechanisms underlying DHH-related DSDs. This is required for better diagnosis, prognosis, and clinical management of these patients.

\section{Conflict of Interest Statement}

The authors have no conflicts of interest to declare.

\section{Funding Sources}

K.L.A and S.P. are funded by an Ideas Grant (APP1156942) from the National Health and Medical Research Council of Australia (NHMRC).

\section{Author Contributions}

All authors wrote the review.

\section{References}

Ayers KL, Thérond PP. Evaluating Smoothened as a G-protein-coupled receptor for Hedgehog signalling. Trends Cell Biol. 2010;20:28798.

Ayers K, van den Bergen J, Robevska G, Listyasari N, Raza J, Atta I, et al. Functional analysis of novel desert hedgehog gene variants improves the clinical interpretation of genomic data and provides a more accurate diagnosis for patients with 46,XY differences of sex development. J Med Genet. 2019;56:434-43.

Bai CB, Stephen D, Joyner AL. All mouse ventral spinal cord patterning by hedgehog is Gli dependent and involves an activator function of Gli3. Dev Cell. 2004;6:103-15.

Baldinotti F, Cavallaro T, Dati E, Baroncelli GI, Bertini V, Valetto A, et al. Novel familial variant of the desert hedgehog gene: Clinical findings in two sisters with $46, \mathrm{XY}$ gonadal dysgenesis or 46,XX karyotype and literature review. Horm Res Paediatr. 2018;89:141-9.

Bangs F, Anderson KV. Primary cilia and mammalian hedgehog signaling. Cold Spring Harb Perspect Biol. 2017;9:a028175.

Barsoum I, Yao HH. Redundant and differential roles of transcription factors Gli1 and Gli2 in the development of mouse fetal Leydig cells. Biol Reprod. 2011;84:894-9.

Barsoum IB, Kaur J, Ge RS, Cooke PS, Yao HH Dynamic changes in fetal Leydig cell populations influence adult Leydig cell populations in mice. FASEB J. 2013;27:2657-66.

Bitgood MJ, McMahon AP. Hedgehog and Bmp genes are coexpressed at many diverse sites of cell-cell interaction in the mouse embryo. Dev Biol. 1995;172:126-38.

Bitgood MJ, Shen L, McMahon AP. Sertoli cell signaling by Desert hedgehog regulates the male germline. Curr Biol. 1996;6:298-304.

Briscoe J, Thérond PP. The mechanisms of Hedgehog signalling and its roles in development and disease. Nat Rev Mol Cell Biol. 2013;14:416-29.
Brokken LJ, Adamsson A, Paranko J, Toppari J. Antiandrogen exposure in utero disrupts expression of desert hedgehog and insulin-like factor 3 in the developing fetal rat testis. Endocrinology. 2009;150:445-51.

Bucay N, Yebra M, Cirulli V, Afrikanova I, Kaido T, Hayek A, et al. A novel approach for the derivation of putative primordial germ cells and Sertoli cells from human embryonic stem cells. Stem Cells. 2009;27:68-77.

Buganim Y, Itskovich E, Hu YC, Cheng AW, Ganz K, Sarkar S, et al. Direct reprogramming of fibroblasts into embryonic Sertoli-like cells by defined factors. Cell Stem Cell. 2012;11: 373-86.

Buglino JA, Resh MD. Hhat is a palmitoylacyltransferase with specificity for N-palmitoylation of Sonic Hedgehog. J Biol Chem. 2008;283:22076-88.

Buonocore F, Clifford-Mobley O, King TFJ, Striglioni N, Man E, Suntharalingham JP, et al. Next-generation sequencing reveals novel genetic variants (SRY, DMRT1, NR5A1, DHH, DHX37) in adults with 46,XY DSD. J Endocr Soc. 2019;3:2341-60.

Callejo A, Torroja C, Quijada L, Guerrero I. Hedgehog lipid modifications are required for Hedgehog stabilization in the extracellular matrix. Development. 2006;133:471-83.

Callier P, Calvel P, Matevossian A, Makrythanasis $\mathrm{P}$, Bernard P, Kurosaka H, et al. Loss of function mutation in the palmitoyl-transferase HHAT leads to syndromic 46,XY disorder of sex development by impeding Hedgehog protein palmitoylation and signaling. PLoS Genet. 2014; 10:e1004340.:

Canto P, Söderlund D, Reyes E, Méndez JP. Mutations in the desert hedgehog (DHH) gene in patients with 46,XY complete pure gonadal dysgenesis. J Clin Endocrinol Metab. 2004;89: 4480-3.

Canto P, Vilchis F, Söderlund D, Reyes E, Méndez JP. A heterozygous mutation in the desert hedgehog gene in patients with mixed gonadal dysgenesis. Mol Hum Reprod. 2005;11:833-6.
Caradu C, Couffinhal T, Chapouly C, Guimbal S, Hollier PL, Ducasse E, et al. Restoring endothelial function by targeting desert hedgehog downstream of Klf2 improves critical limb ischemia in adults. Circ Res. 2018;123:105365.

Carpenter D, Stone DM, Brush J, Ryan A, Armanini M, Frantz G, et al. Characterization of two patched receptors for the vertebrate hedgehog protein family. Proc Natl Acad Sci U S A. 1998;95:13630-4.

Chamoun Z, Mann RK, Nellen D, von Kessler DP, Bellotto M, Beachy PA, et al. Skinny hedgehog, an acyltransferase required for palmitoylation and activity of the hedgehog signal. Science. 2001;293:2080-4.

Chapouly C, Yao Q, Vandierdonck S, Larrieu-Lahargue F, Mariani JN, Gadeau AP, et al. Impaired Hedgehog signalling-induced endothelial dysfunction is sufficient to induce neuropathy: implication in diabetes. Cardiovasc Res. 2016;109:217-27.

Chen M, Wang X, Wang Y, Zhang L, Xu B, Lv L, et al. Wt1 is involved in Leydig cell steroid hormone biosynthesis by regulating paracrine factor expression in mice. Biol Reprod. 2014;90:71.

Chen Y, Li C, Ji W, Wang L, Chen X, Zhao S, et al. Differentiation of human adipose derived stem cells into Leydig-like cells with molecular compounds. J Cell Mol Med. 2019;23: 5956-69.

Chung JW, Pask AJ, Renfree MB. Seminiferous cord formation is regulated by hedgehog signaling in the marsupial. Biol Reprod. 2012;86:80.

Clark AM, Garland KK, Russell LD. Desert hedgehog (Dhh) gene is required in the mouse testis for formation of adult-type Leydig cells and normal development of peritubular cells and seminiferous tubules. Biol Reprod. 2000;63:1825-38.

Corbit KC, Aanstad P, Singla V, Norman AR, Stainier DY, Reiter JF. Vertebrate Smoothened functions at the primary cilium. Nature. 2005;437:1018-21. 
Darde TA, Lecluze E, Lardenois A, Stévant I, Alary N, Tüttelmann F, et al. The ReproGenomics Viewer: a multi-omics and cross-species resource compatible with single-cell studies for the reproductive science community. Bioinformatics. 2019;35:3133-39.

Darde TA, Sallou O, Becker E, Evrad B, Monjeaud C, Le Bras Y, et al. The ReproGenomics Viewer: an integrative cross-species toolbox for the reproductive science community. Nucleic Acids Res. 2015;43:W109-16.

Das DK, Sanghavi D, Gawde H, Idicula-Thomas S, Vasudevan L. Novel homozygous mutations in Desert hedgehog gene in patients with $46, \mathrm{XY}$ complete gonadal dysgenesis and prediction of its structural and functional implications by computational methods. Eur J Med Genet. 2011;54:e529-34.

Dennis JF, Kurosaka H, Iulianella A, Pace J, Thomas N, Beckham S, et al. Mutations in Hedgehog acyltransferase (Hhat) perturb Hedgehog signaling, resulting in severe acrania-holoprosencephaly-agnathia craniofacial defects. PLoS Genet. 2012;8:e1002927.:

Doheny D, Manore SG, Wong GL, Lo HW. Hedgehog signaling and truncated GLI1 in cancer. Cells. 2020;9:2114.

Eggers S, Ohnesorg T, Sinclair A. Genetic regulation of mammalian gonad development. Nat Rev Endocrinol. 2014;10:673-83.

Eggers S, Sadedin S, van den Bergen JA, Robevska G, Ohnesorg T, Hewitt J, et al. Disorders of sex development: insights from targeted gene sequencing of a large international patient cohort. Genome Biol. 2016;17:243.

Elzaiat M, Flatters D, Sierra-Díaz DC, Legois B, Laissue P, Veitia RA. DHH pathogenic variants involved in 46,XY disorders of sex development differentially impact protein selfcleavage and structural conformation. Hum Genet. 2020;139:1455-70.

Fan J, Akabane H, Zheng X, Zhou X, Zhang L, Liu $Q$, et al. Male germ cell-specific expression of a novel Patched-domain containing gene Ptchd3. Biochem Biophys Res Commun. 2007;363:757-61.

Findakly S, Daggubati V, Garcia G, LaStella SA, Choudhury A, Tran C, et al. Sterol and oxysterol synthases near the ciliary base activate the Hedgehog pathway. J Cell Biol. 2021;220: e202002026.

Fowler PA, Cassie S, Rhind SM, Brewer MJ, Collinson JM, Lea RG, et al. Maternal smoking during pregnancy specifically reduces human fetal desert hedgehog gene expression during testis development. J Clin Endocrinol Metab. 2008;93:619-26.

Green JS, Parfrey PS, Harnett JD, Farid NR, Cramer BC, Johnson G, et al. The cardinal manifestations of Bardet-Biedl syndrome, a form of Laurence-Moon-Biedl syndrome. N Engl J Med. 1989;321:1002-9.

Hollier P-L, Chapouly C, Diop A, Guimbal S, Cornuault L, Gadeau A-P, et al. Full-length dhh and N-terminal shh act as competitive antagonists to regulate angiogenesis and vascular permeability. Cardiovasc Res. 2020.
Huangfu D, Liu A, Rakeman AS, Murcia NS, Niswander L, Anderson KV. Hedgehog signalling in the mouse requires intraflagellar transport proteins. Nature. 2003;426:83-7.

Incardona JP, Lee JH, Robertson CP, Enga K, Kapur RP, Roelink H. Receptor-mediated endocytosis of soluble and membrane-tethered Sonic hedgehog by Patched-1. Proc Natl Acad Sci U S A. 2000;97:12044-9.

Iriana S, Asha K, Repak M, Sharma-Walia N. Hedgehog signaling: implications in cancers and viral infections. Int J Mol Sci. 2021;22(3): 1042.

Kawai Y, Noguchi J, Akiyama K, Takeno Y, Fujiwara Y, Kajita S, et al. A missense mutation of the Dhh gene is associated with male pseudohermaphroditic rats showing impaired Leydig cell development. Reproduction. 2011; 141:217-25.

Knarston IM, Pachernegg S, Robevska G, Ghobrial I, Er PX, Georges E, et al. An in Vitro differentiation protocol for human embryonic bipotential gonad and testis cell development. Stem Cell Reports. 2020;15:1377-91.

Kroft TL, Patterson J, Won Yoon J, Doglio L, Walterhouse DO, Iannaccone PM, et al. GLI1 localization in the germinal epithelial cells alternates between cytoplasm and nucleus: upregulation in transgenic mice blocks spermatogenesis in pachytene. Biol Reprod. 2001;65:1663-71.

Lee RT, Zhao Z, Ingham PW. Hedgehog signalling. Development. 2016;143:367-72.

Lewis PM, Dunn MP, McMahon JA, Logan M, Martin JF, St-Jacques B, et al. Cholesterol modification of sonic hedgehog is required for long-range signaling activity and effective modulation of signaling by Ptc1. Cell. 2001; 105:599-612.

Li L, Dong J, Yan L, Yong J, Liu X, Hu Y, et al. Single-cell RNA-Seq analysis maps development of human germline cells and gonadal niche interactions. Cell Stem Cell. 2017;20: 891-2.

Mann RK, Beachy PA. Novel lipid modifications of secreted protein signals. Annu Rev Biochem. 2004;73:891-923.

Marigo V, Davey RA, Zuo Y, Cunningham JM, Tabin CJ. Biochemical evidence that Patched is the Hedgehog receptor. Nature. 1996;384: 176-9.

Morales CR, Fox A, El-Alfy M, Ni X, Argraves WS. Expression of Patched-1 and Smoothened in testicular meiotic and post-meiotic cells. Microsc Res Tech. 2009;72:809-15.

Motoyama J, Takabatake T, Takeshima K, Hui C. Ptch2, a second mouse Patched gene is co-expressed with Sonic hedgehog. Nat Genet. 1998;18:104-6.

Neocleous V, Fanis P, Cinarli F, Kokotsis V, Oulas A, Toumba M, et al. 46,XY complete gonadal dysgenesis in a familial case with a rare mutation in the desert hedgehog $(\mathrm{DHH})$ gene. Hormones (Athens). 2019;18:315-20.
Nivelon A, Nivelon JL, Mabille JP, Maroteaux P, Feldman JP, Douvier S, et al. New autosomal recessive chondrodysplasia-pseudohermaphrodism syndrome. Clin Dysmorphol. 1992;1:221-7.

Nygaard MB, Almstrup K, Lindbæk L, Christensen ST, Svingen T. Cell context-specific expression of primary cilia in the human testis and ciliary coordination of Hedgehog signalling in mouse Leydig cells. Sci Rep. 2015;5: 10364.

O'Hara WA, Azar WJ, Behringer RR, Renfree MB, Pask AJ. Desert hedgehog is a mammalspecific gene expressed during testicular and ovarian development in a marsupial. BMC Dev Biol. 2011;11:72.

Paris F, Flatters D, Caburet S, Legois B, Servant N, Lefebvre $\mathrm{H}$, et al. A novel variant of $\mathrm{DHH}$ in a familial case of 46,XY disorder of sex development: Insights from molecular dynamics simulations. Clin Endocrinol (Oxf). 2017;87: $539-44$.

Park SY, Tong M, Jameson JL. Distinct roles for steroidogenic factor 1 and desert hedgehog pathways in fetal and adult Leydig cell development. Endocrinology. 2007;148:3704-10.

Pathi S, Pagan-Westphal S, Baker DP, Garber EA, Rayhorn P, Bumcrot D, et al. Comparative biological responses to human Sonic, Indian, and Desert hedgehog. Mech Dev. 2001;106: $107-17$

Pepinsky RB, Zeng C, Wen D, Rayhorn P, Baker $\mathrm{DP}$, Williams KP, et al. Identification of a palmitic acid-modified form of human Sonic hedgehog. J Biol Chem. 1998;273:14037-45.

Persengiev SP, Kondova II, Millette CF, Kilpatrick DL. Gli family members are differentially expressed during the mitotic phase of spermatogenesis. Oncogene. 1997;14:2259-64.

Pettigrew CA, Asp E, Emerson CP Jr. A new role for Hedgehogs in juxtacrine signaling. Mech Dev. 2014;131:137-49.

Pierucci-Alves F, Clark AM, Russell LD. A developmental study of the Desert hedgehog-null mouse testis. Biol Reprod. 2001;65:1392-402.

Porter JA, Young KE, Beachy PA. Cholesterol modification of hedgehog signaling proteins in animal development. Science. 1996;274: 255-9.

Reiter JF, Leroux MR. Genes and molecular pathways underpinning ciliopathies. Nat Rev Mol Cell Biol. 2017;18:533-47.

Renault MA, Chapouly C, Yao Q, Larrieu-Lahargue F, Vandierdonck S, Reynaud A, et al. Desert hedgehog promotes ischemia-induced angiogenesis by ensuring peripheral nerve survival. Circ Res. 2013;112:762-70.

Rodriguez Gutierrez D, Eid W, Biason-Lauber A. A human gonadal cell model from induced pluripotent stem cells. Front Genet. 2018;9: 498.

Rohatgi R, Milenkovic L, Scott MP. Patched1 regulates hedgehog signaling at the primary cilium. Science. 2007;317:372-6. 
Rothacker KM, Ayers KL, Tang D, Joshi K, van den Bergen JA, Robevska G, et al. A novel, homozygous mutation in desert hedgehog (DHH) in a 46,XY patient with dysgenetic testes presenting with primary amenorrhoea: a case report. Int J Pediatr Endocrinol. 2018; 2018:2.

Sasai N, Toriyama M, Kondo T. Hedgehog signal and genetic disorders. Front Genet. 2019;10: 1103.

Sato NS, Maekawa R, Ishiura H, Mitsui J, Naruse $\mathrm{H}$, Tokushige SI, et al. Partial duplication of DHH causes minifascicular neuropathy: A novel mutation detection of $\mathrm{DHH}$. Ann Clin Transl Neurol. 2017;4:415-21.

Sepponen K, Lundin K, Knuus K, Väyrynen P, Raivio T, Tapanainen JS, et al. The Role of sequential BMP signaling in directing human embryonic stem cells to bipotential gonadal cells. J Clin Endocrinol Metab. 2017;102: 4303-14.

Shima JE, McLean DJ, McCarrey JR, Griswold MD. The murine testicular transcriptome: characterizing gene expression in the testis during the progression of spermatogenesis. Biol Reprod. 2004;71:319-30.

Soliman AT, Rajab A, AlSalmi I, Asfour MG. Empty sellae, impaired testosterone secretion, and defective hypothalamic-pituitary growth and gonadal axes in children with BardetBiedl syndrome. Metabolism. 1996;45:12304.
Sugie K, Futamura N, Suzumura A, Tate G, Umehara F. Hereditary motor and sensory neuropathy with minifascicle formation in a patient with 46,XY pure gonadal dysgenesis: a new clinical entity. Ann Neurol. 2002;51:3858.

Szczepny A, Hime GR, Loveland KL. Expression of hedgehog signalling components in adult mouse testis. Dev Dyn. 2006;235:3063-70.

Tajouri A, Kharrat M, Hizem S, Zaghdoudi H, M'Rad R, Simic-Schleicher G, et al. In vitro functional characterization of the novel $\mathrm{DHH}$ mutations p. (Asn337Lysfs*24) and p. (Glu212Lys) associated with gonadal dysgenesis. Hum Mutat. 2018;39:2097-109.

Tate G, Satoh H, Endo Y, Mitsuya T. Assignment of desert hedgehog (DHH) to human chromosome bands 12q12-->q13.1 by in situ hybridization. Cytogenet Cell Genet. 2000;88: 93-4.

Thauvin-Robinet C, Mugneret F, Callier P, Chouchane M, Garron E, Manceau E, et al. Unique survival in chrondrodysplasia-hermaphrodism syndrome. Am J Med Genet A. 2005;132A:335-7.

Umehara F, Yamaguchi N, Kodama D, Takenaga S, Kiwaki T, Sonoda Y, et al. Polyneuropathy with minifascicle formation in a patient with 46 , XY mixed gonadal dysgenesis. Acta Neuropathol. 1999;98:309-12.

Umehara F, Tate G, Itoh K, Yamaguchi N, Douchi T, Mitsuya T, et al. A novel mutation of desert hedgehog in a patient with 46,XY partial gonadal dysgenesis accompanied by minifascicular neuropathy. Am J Hum Genet. 2000;67: $1302-5$.
Walterhouse DO, Lamm ML, Villavicencio E, Iannaccone PM. Emerging roles for hedgehog-patched-Gli signal transduction in reproduction. Biol Reprod. 2003;69:8-14.

Werner R, Merz H, Birnbaum W, Marshall L, Schröder T, Reiz B, et al. 46,XY gonadal dysgenesis due to a homozygous mutation in desert Hedgehog $(\mathrm{DHH})$ identified by EXOME sequencing. J Clin Endocrinol Metab. 2015; 100:E1022-9.

Yang Y, Li Z, Wu X, Chen H, Xu W, Xiang Q, et al. Direct reprogramming of mouse fibroblasts toward Leydig-like cells by defined factors. Stem Cell Reports. 2017;8:39-53.

Yang Y, Su Z, Xu W, Luo J, Liang R, Xiang Q, et al. Directed mouse embryonic stem cells into Leydig-like cells rescue testosterone-deficient male rats in vivo. Stem Cells Dev. 2015;24: 459-70.

Yao HH, Capel B. Disruption of testis cords by cyclopamine or forskolin reveals independent cellular pathways in testis organogenesis. Dev Biol. 2002;246:356-65.

Yao HH, Whoriskey W, Capel B. Desert Hedgehog/Patched 1 signaling specifies fetal Leydig cell fate in testis organogenesis. Genes Dev. 2002;16:1433-40.

Ye L, Li X, Li L, Chen H, Ge RS. Insights into the development of the adult Leydig cell lineage from stem Leydig cells. Front Physiol. 2017;8: 430

Zeng X, Goetz JA, Suber LM, Scott WJ Jr., Schreiner CM, Robbins DJ. A freely diffusible form of Sonic hedgehog mediates long-range signalling. Nature. 2001;411:716-20. 